\title{
The Fusarium virguliformeToxin FvTox1 Causes Foliar Sudden Death Syndrome-Like Symptoms in Soybean
}

\author{
Hargeet K. Brar, ${ }^{1,2}$ Sivakumar Swaminathan, ${ }^{1}$ and Madan K. Bhattacharyyaa ${ }^{1,2}$ \\ ${ }^{1}$ Department of Agronomy and ${ }^{2}$ Interdepartmental Genetics Graduate Major Program, lowa State University, Ames, lowa \\ 50011-1010, U.S.A.
}

Submitted 22 December 2010. Accepted 17 May 2011.

Fusarium virguliforme causes sudden death syndrome (SDS) in soybean. The pathogen has never been isolated from diseased foliar tissues; therefore, one or more toxins have been considered to cause foliar SDS development. Cell-free $F$. virguliforme culture filtrates containing a toxin causes foliar SDS in soybean. A low-molecular-weight protein of approximately $13.5 \mathrm{kDa}$ (FvTox1), purified from $F$. virguliforme culture filtrates, produces foliar SDS-like symptoms in cut soybean seedlings. Anti-FvTox1 monoclonal antibodies raised against the purified FvTox1 were used in isolating the FvToxI gene. In the presence of light, recombinant FvTox1 protein expressed in an insect cell line resulted in chlorosis and necrosis in soybean leaf disks that are typical foliar SDS symptoms. SDS-susceptible but not the SDS-resistant soybean lines were sensitive to the baculovirus-expressed toxin. The requirement of light for foliar SDS-like symptom development indicates that FvTox1 induces foliar SDS in soybean, most likely through production of free radicals by interrupting photosynthesis.

Host-selective toxins (HST) have been shown to induce disease symptoms in susceptible plants. Many of the fungal toxins are proteinaceous (Friesen et al. 2008), e.g., VD18.5 of Verticillium dahliae (Palmer et al. 2005), AB toxin of Alternaria brassicola (Otani et al. 1998), AP toxin of Alternaria panax (Quayyum et al. 2003), cerato-platanin of Ceratocystis fimbriata (Pazzagli et al. 1999), nep1 toxin of Fusarium oxysporum f. sp. erythroxli (Bailey 1995), Ptr ToxA and Ptr ToxB of Pyrenophora tritici-repentis (Ballance et al. 1989; Martinez et al. 2001; Tomas et al. 1990; Tuori et al. 1995; Zhang et al. 1997), and the five toxins identified from Stagonospora nodorum (Abeysekara et al. 2009; Friesen et al. 2006, 2007, 2008; Lui et al. 2004).

Fusarium species are among the most virulent toxin-producing fungi (Creppy 2002). The toxins produced by Fusarium affect either animals (zearalenone) or plants (fusaric acid) and, in some cases, both plants and animals (e.g., enniatins, beauvericins, moniliformin, and fumonisins produced by Fusarium verticillioides [Desjardins and Hohn 1997]). Sudden death syn-

Sequence data is available in the EMBL and GenBank data libraries under accession numbers FOXG_06271.2 (Fo-Pp), FVEG_04124.2 (Fver-Hp), EEU40946.1 (Nh-Hp), XP 389746.1(Gz-Hp), and JF440964 (FvTox1.

Corresponding author: Madan K. Bhattacharyya;

E-mail: mbhattac@iastate.edu; Telephone: +1.515.294.2505;

Fax: +1.515.294.2299

* The $\boldsymbol{e}$-Xtra logo stands for "electronic extra" and indicates that four supplementary figures are published online and that Figures 1 and 2 appear in color online. drome (SDS), a serious emerging soybean disease in the United States (Wrather and Koenning 2006), is caused by the soil-borne fungal pathogen Fusarium virguliforme, previously known as $F$. solani f. sp. glycines (Roy et al. 1989, 1997; Rupe 1989). In the United States, the disease was reported first in Arkansas in 1971 (Hirrel 1987). Subsequently, the pathogen has gradually spread to the north, including Minnesota (Malvick 2006). To date, at least 15 states are affected by this disease (Malvick 2006; Roy et al. 1997; Wrather and Koenning 2006; Ziems et al. 2006).

In South America, Fusarium tucumaniae causes SDS in soybean (Aoki et al. 2003). F. virguliforme and F. tucumaniae are closely related species (Aoki et al. 2003; O'Donnell 2000; O'Donnell et al. 2010). Both species attack soybean roots and cause root necrosis. Neither species has ever been isolated from the above-ground diseased tissues (Roy et al. 1989; Rupe 1989). Initially SDS resistance was thought to be encoded by single genes (Stephens et al. 1993). Now, it is known that SDS resistance is governed by at least 14 quantitative trait loci located in nine linkage groups (Hnetkovsky et al. 1996; Kazi et al. 2008).

There are two components of the SDS, i.e., root necrosis and foliar SDS. At the initial stage, the foliar SDS is characterized by interveinal chlorosis and necrosis of leaves. In the severe form of the disease, leaves, flowers, and pods fall off soybean plants, leading to severe yield reduction (Hershman 1990; Hirrel 1987; Roy et al. 1997). F. virguliforme excretes one or more toxins into culture media that produces foliar SDS-like symptoms in 3-week-old cut soybean seedlings ( $\mathrm{Li}$ et al. 1999). It is speculated that one or more toxins released by $F$. virguliforme to the soybean roots causes foliar SDS (Li et al. 1999; Roy et al. 1989; Rupe 1989). A $17-\mathrm{kDa}$ protein that causes necrosis in soybean tissues was partially purified from $F$. virguliforme culture filtrates (Jin et al. 1996). However, the gene encoding the $17-\mathrm{kDa}$ protein has never been isolated. Here, we report the identification of the FvToxl gene, which encodes a $13.5-\mathrm{kDa}$ acidic protein. Both native FvTox 1 of the cell-free $F$. virguliforme culture filtrates and FvTox1 expressed in a baculovirus-infected insect cell line cause chlorosis and necrosis in soybean leaves. The SDS-susceptible but not the SDS-resistant soybean lines are highly sensitive to the expressed FvTox1 protein. These results indicate that FvTox 1 is most likely a major pathogenicity factor for foliar SDS development in soybean.

\section{RESULTS}

A low-molecular-weight protein causes

foliar SDS-like symptoms.

We applied a previously reported 'stem-cutting' bioassay for purifying one or more candidate toxins secreted by $F$. virguliforme into culture filtrates (Ji et al. 2006; Li et al. 1999). Ly- 
ophilized cell-free $F$. virguliforme culture filtrate was separated in a Sephacryl S300HR column, and 1-ml fractions were evaluated for possible phytotoxic activity. Fractions 33 to 57 produced foliar SDS-like symptoms in cut seedlings of the soybean cultivar Williams 82 . Fractions 38 to 46 produced the most severe foliar SDS symptoms.

Column fractions showing phytotoxic activities (Fig. 1A) were pooled and lyophilized and were then separated on native polyacrylamide gels. The gels were fractionated into six horizontal fractions, I to VI. Proteins of individual fractions were eluted for determination of their possible phytotoxic activities (Fig. 2A). Eluted proteins from fractions I to $\mathrm{V}$ did not produce any symptoms (Fig. 2B), as in the water control (data not shown); whereas, fraction VI was able to produce foliar SDS symptoms in a stem-cutting assay (Fig. 2C). The purified protein from fraction VI was resolved in both native and denaturing gels. Based on the mobility on a denaturing gel, the esti- mated size of the purified protein was approximately $13.5 \mathrm{kDa}$ (Fig. 2E). We named this protein FvTox1.

\section{Monoclonal anti-FvTox1 antibodies suppressed the phytotoxic activity of $\boldsymbol{F}$. virguliforme culture filtrates.}

The purified FvTox1 (Fig. 2E) was used to raise polyclonal antibodies in mice. Polyclonal antibodies of one mouse showed strong cross-reactivity to FvTox1. The splenocytes from this mouse were fused to the mice myeloma cell line to create hybridoma clones. Through enzyme-linked immunosorbent assay (ELISA) and Western blot analyses, extracts from hybridoma cell lines were tested for their possible cross-reactivity to FvTox1, and four monoclonal anti-FvTox1 antibodies were identified (Supplementary Fig. S1). The monoclonal antibodies were then investigated for their binding-specificities to the toxins of $F$. virguliforme culture filtrates. In the presence of increasing amounts of individual antibodies in an immuno-
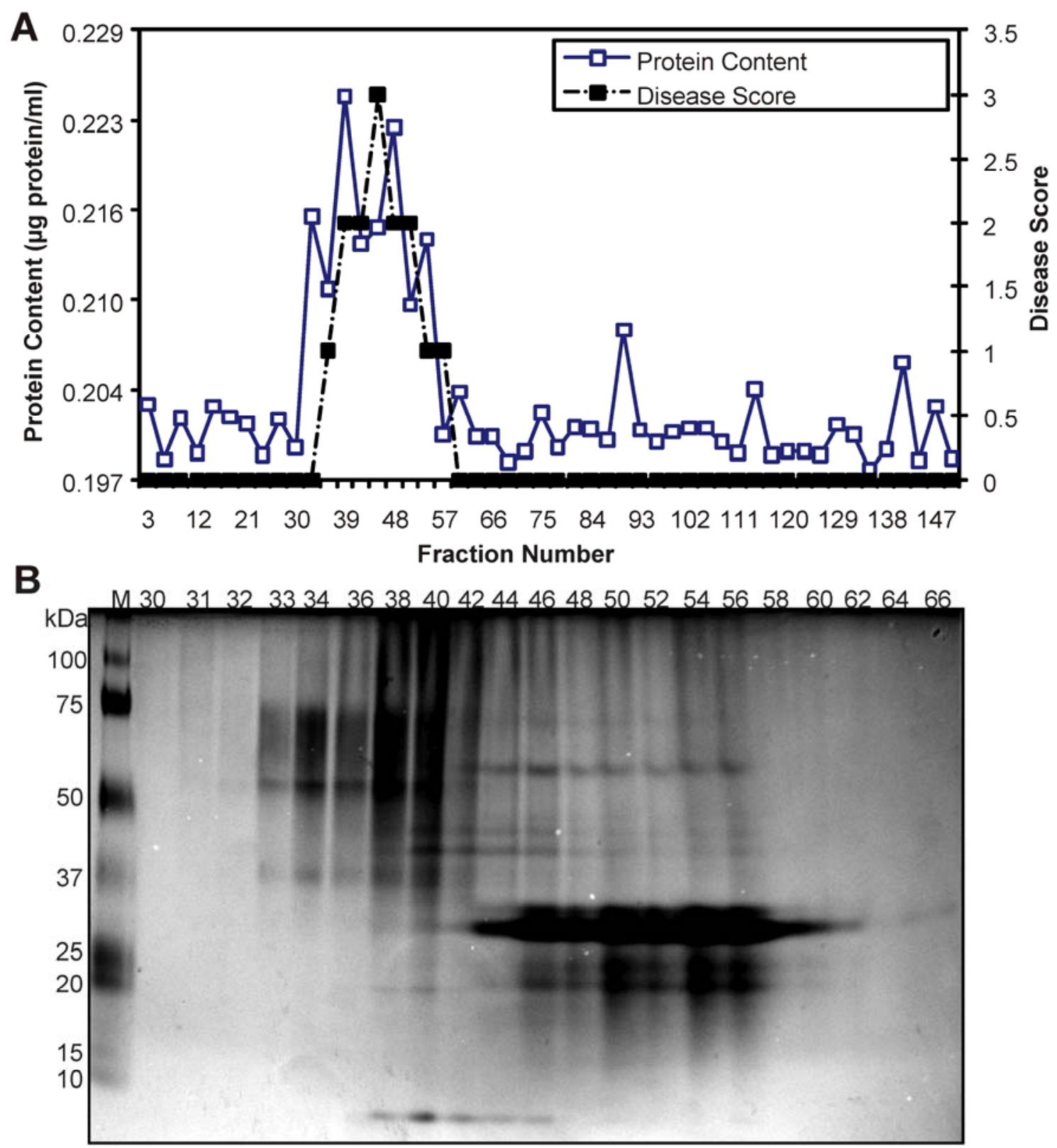

Fig. 1. Purification of the one or more phytotoxic proteins from cell-free Fusarium virguliforme culture filtrates by size exclusion chromatography. A, Association of disease severity with protein concentrations in individual column fractions. Protein contents of individual 1-ml column fractions were determined by Bradford assay. sudden death syndrome symptoms were scored according to Ji and associates (2006). B, Electrophoresis of column fractions in a $14 \%$ native polyacrylamide gel. The stem-cutting assay was conducted three times and results of one experiment are presented. 
suppression experiment, the extent of foliar SDS symptom development was reduced. Maximum reduction in symptom development was observed for the 7E8 antibody (Supplementary Fig. S2). These results suggested that monoclonal antibodies were specific to one or more toxins of the cell-free $F$. virguliforme culture filtrates that induce foliar SDS.

\section{FvTox1 encodes a small peptide.}

We applied an immunoscreening procedure to clone the gene. Three putative cDNA clones were isolated from screening of approximately 500,000 plaque-forming units with the antiFvTox1 monoclonal antibodies. The clones were sequenced. One of the clones contains the N-terminal sequence of the purified FvTox 1 protein. Protein expressed by this clone was recognized by all four monoclonal anti-FvTox 1 antibodies (data not shown). The FvTox1 showed high similarities to hypothetical proteins of Nectria haematococca (GenBank number EEU40946), Fusarium oxysporum (Broad Institute number FOXG_06271.2), Fusarium verticillioides (Broad Institute number FVEG_04124.2), and Gibberella zeae (GenBank number XM_389746) (Supplementary Fig. S3). The percent identity of FvTox1 to FOXG_06271.2, FVEG_04124.2, EEU40946.1, and XP 389746.1 is $67,60,91$, and 59, respectively. The deduced FvTox1 (pro-FvTox1) protein has a predicted isoelectric point of 4.47 and a molecular mass of approximately $20 \mathrm{kDa}$ (Expasy Findmod tool). The calculated molecular mass of the mature FvTox 1 purified from the $F$. virguliforme culture filtrate was $15.5 \mathrm{kDa}$ (32 amino acids [aa] shorter than pro-FvTox1), which is close to the estimated molecular mass of approximately $13.5 \mathrm{kDa}$, based on mobility of the purified protein on a denaturing gel (Fig. 2E).

\section{FvTox1 is a single gene.}

A genomic library was constructed from the $F$. virguliforme genomic DNA, and seven clones were identified using the FvToxl cDNA as the probe. All seven clones showed identical restriction patterns, suggesting that FvToxl is a single-copy gene (data not shown). The copy number of FvToxl was investigated also by conducting low-stringency Southern blot analysis and by analyzing the $F$. virguliforme genome sequence.
Southern hybridization experiments suggested that FvToxl is most likely a single-copy gene (Fig. 3A). The recently assembled $F$. virguliforme genome sequence (AEYB00000000; S. Srivastava, X. Huang, and M. K. Bhattacharyya, unpublished) was analyzed for possible FvToxl homologs. Only FvToxl was identified from the $F$. virguliforme genome, confirming that FvToxl is a single-copy gene.

A 3-kb genomic fragment containing FvToxl was sequenced and analyzed using the FGENESH 2.6 prediction program (Salamov and Solovyev 2000). The TATA box was found to be located $135 \mathrm{bp}$ upstream of the start codon. The gene contains two small introns (61 and 50 bp) (Fig. 3B; accession number JF440964). Both introns contain consensus eukaryotic splice sites (5'-GT and 3'-AG). The predicted exon and intron boundaries were confirmed by comparing the gene sequence with the cDNA sequence.

\section{FvTox1 is processed from a pro-peptide.}

In order to establish phytotoxic function of the candidate FvToxl gene, it was expressed in the baculovirus-infected insect cell line Sf21. Both pro-FvToxl (encoding the entire open reading frame; pro-toxin, pro-peptide) and mature-FvToxl (encoding the secreted peptide purified from $F$. virguliforme culture filtrates) genes were cloned into the expression vector pFastBac1. His-tag was fused to the N-termini of both forms of the toxin gene. The pro-FvTox1 protein was smaller in size as compared with mature-FvTox1 (Fig. 4B). Western blot analyses showed that the $\mathrm{N}$-terminus of pro-FvTox 1 was cleaved in insect cells (Fig. 4C). To determine the cleavage site in pro-FvTox1, N-terminal sequencing was conducted. The first 19 aa of pro-FvTox1 were excised in insect cells (Fig. 4D). The cleavage site matched with the predicted signal peptide cleavage site (SignalP 3.0 server; Bendtsen et al. 2004). Presumably, the N-terminal first 19 aa of FvTox 1 are cleaved off for its translocation through the endoplasmic reticulum membrane into the cytoplasm (Bendtsen et al. 2004). FvTox1 was also secreted by insect cells into the culture medium (Fig. $4 \mathrm{E}$ ). The N-terminal sequencing of FvTox1 purified from cellfree $F$. virguliforme culture filtrate revealed earlier that the first 32 aa are cleaved prior to secretion into culture medium. Search
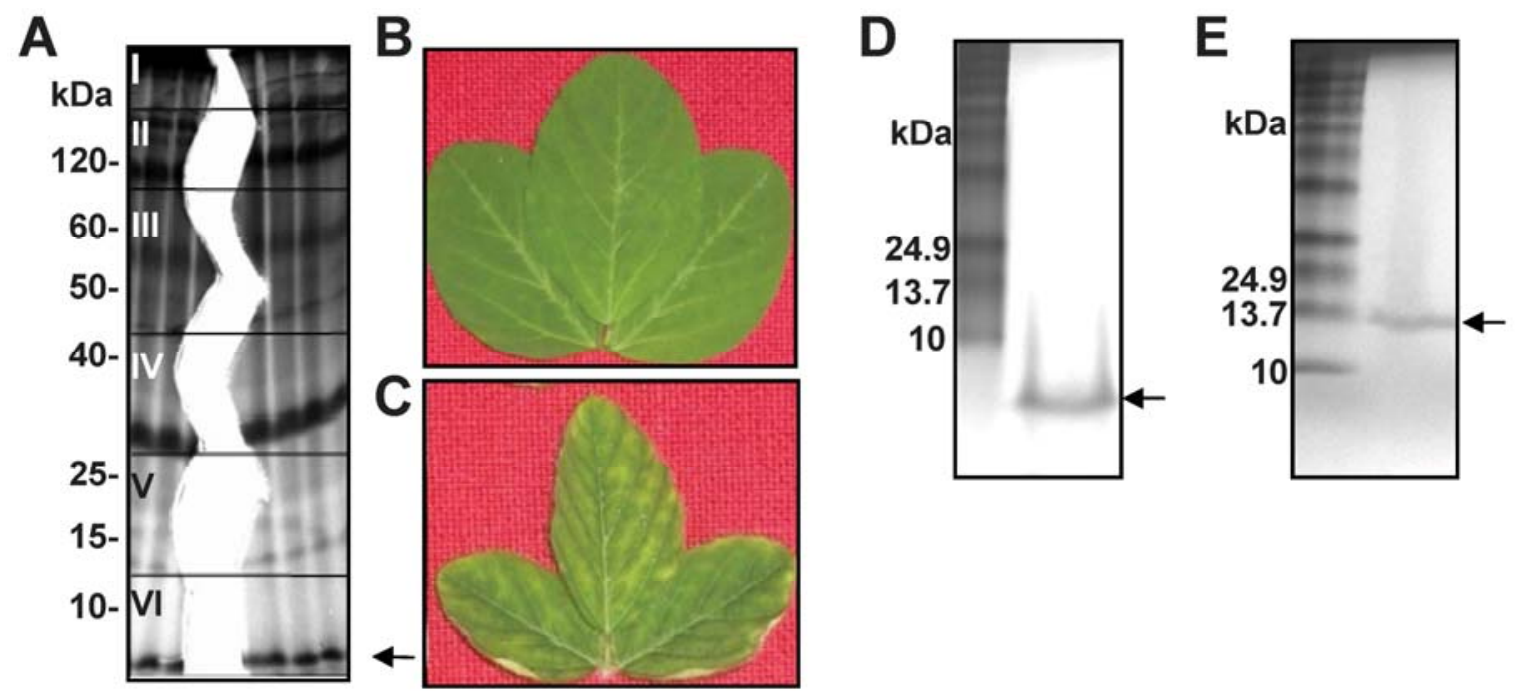

Fig. 2. Identification of a protein that showed phytotoxic activity. A, A $14 \%$ native polyacrylamide gel shows the protein profile of cell-free Fusarium virguliforme culture filtrates. The gel was divided into three longitudinal sections. Two outer sections were stained with Coomassie brilliant blue to identify protein profiles. The mddle unstained portion of gel was divided into six horizontal fractions as shown in A. Proteins were extracted from each of these six fractions and were tested for their phytotoxic activity in three stem-cutting assays. B, Fractions I through V did not show any phytotoxicity. C, Fraction VI produced foliar sudden death syndrome symptoms, when it was fed to cut soybean seedlings. D, Electrophoresis of the purified protein FvTox 1 in a $12 \%$ native polyacrylamide gel. E, Sodium dodecyl sulfate polyacrylamide gel electrophoresis of purified FvTox1. Under denaturing conditions, the molecular mass of FvTox 1 was approximately $13.5 \mathrm{kDa}$. Arrows indicate the purified FvTox 1 molecule. 


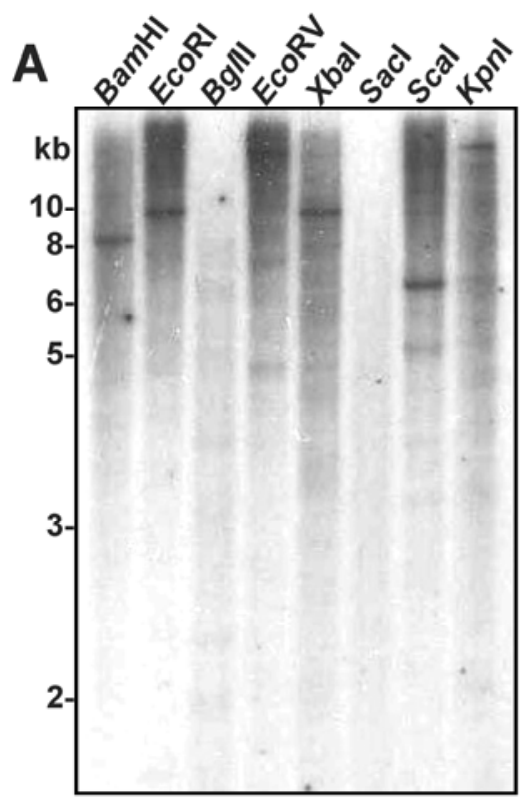

B

tcatcctgtacctcgcaaccatggaagggagagctggacataagacaagctcttgTATAA gaaggctcgacccgaaggtgatggactgccgttgaatctcggcaatctcacaagccacct ctacaattacagcttgttctttacaatcatactgtttgtactctttcacacccaccaca accatcatcatgaagtccacattcacccttgcggctctgtcgctctttgcctcccaatgc atgaagtccacattcacccttgcggctctgtcgetctttgcctcccaatgcctcgccgcc $\begin{array}{llllllllllllllllllll}M & K & S & T & F & T & L & A & A & L & S & L & F & A & S & \& & C & L & A & A\end{array}$ tcggtcgacatgtggtctgcccccetcagcgcccggagcgcagccagatacgagcccatc $\begin{array}{llllllllllllllllllllllllllllll}S & V & D & M & W & S & A & P & L & S & A & R & S & A & A & R & Y & E & P & I\end{array}$ gaccccgaggtgatcaagtctcgcctcggcaccacgcctgaggagtacgatccagagaac $\begin{array}{llllllllllllllllllll}D & P & E & V & I & K & S & R & L & G & T & T & P & E & E & Y & D & P & E & N\end{array}$

AggcacgctggaatgGTaaggattcacccaacagacactgtgctcaacaacacccatcgc R $\quad H \quad A \quad G \quad M$

taacggcggctcccAGgtctacttttgccgtgaggaaaactggggtcctccetgcttcgtc $\begin{array}{llllllllllllllllllllll}V & Y & F & C & R & E & E & N & W & G & P & P & C & F & \text { V }\end{array}$

tactaccccgaactcgagtacacatgctccgagcttgggccggagcttgcaggccatgtt $\begin{array}{llllllllllllllllllll}Y & Y & P & E & L & E & Y & T & C & S & E & L & G & P & E & L & A & G & H & \text { V }\end{array}$

ggttctgtatttgtcgaggctggtgccatctgccggatggcaacGTacgtgaccetctca $\begin{array}{lllllllllllllllllllllllllll}G & S & V & F & V & E & A & G & A & I & C & R & M & A & T\end{array}$

TacatgtcgaataccgattactgacaaactgcAGactcagcgcccaggaccgatgcgcc L $\quad S \quad A \quad Q \quad D \quad R \quad C \quad A$

ccgatcgagttctttgcctggcccgagactgcggctggctggcccgacctcttccaaagg

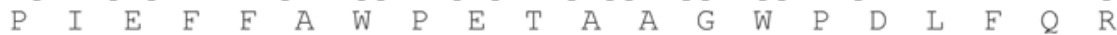

gacggcccogacggcaagggcaagcttggcgatgagacgactcactttacgtgcgccgaa

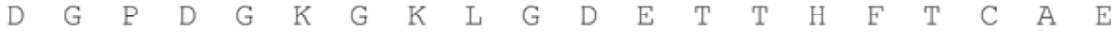

tgtaccaactgtgtgcgcaacccacag

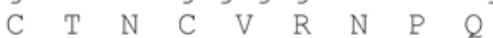

Fig. 3. FvTox 1 is encoded by a single gene. A, Low-stringency Southern analysis of Fusarium virguliforme DNA revealed a single strongly hybridizing DNA fragments in most restriction endonuclease digestions. B, Sequence of FvToxl gene encoding FvTox1. The TATA box is shown in bold. The start and end of introns are shown by bold capital letters.

A

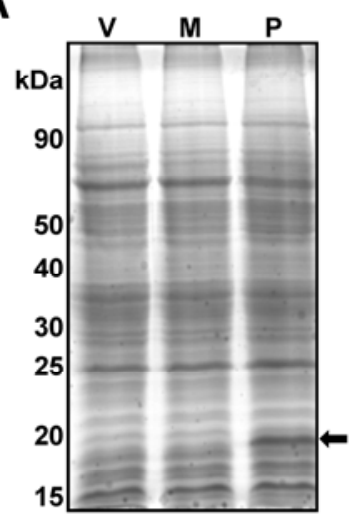

B

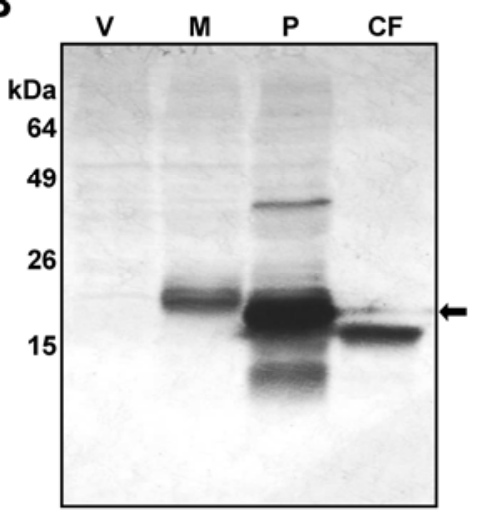

C

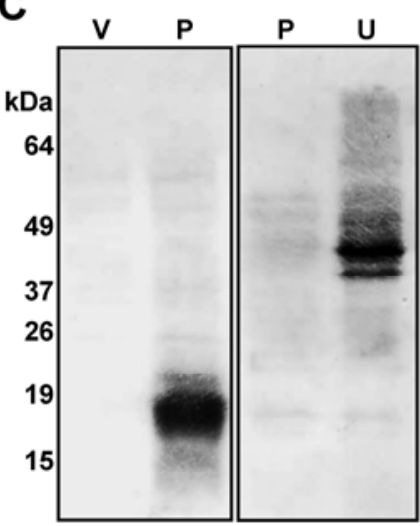

E

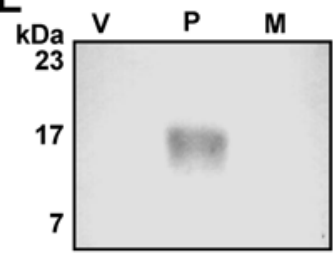

D

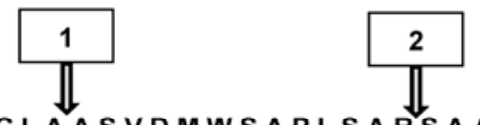

MKSTFTLAALSLFASQCLAASVDMWSAPLSARSAARYEPIDPEVIKSRLGTTPEEYDPENRHAG MVYFCRE ENWGPPCFVYYPELEYTCSELGPELAGHVGSVFVEAGAICRMATLSAQDRCAPIEFF AWPETAAGWPDLLQRDGPDGKGKLGDETAHFTCAECTNCVRNPQ

Fig. 4. Expression of FvTox 1 in an insect cell line. A, Denaturing polyacrylamide gel electrophoresis (PAGE) analysis of expressed FyTox 1 proteins. Insect Sf21 cells infected with either empty vector (V), mature-FvToxl (M), or pro-FvToxl (P) were harvested 72 h postinfection. Equal amounts of the whole-cell lysates were separated in a $12 \%$ sodium dodecyl sulfate-PAGE gel and were stained with Coomassie brilliant blue; approximately 17-kDa expressed proFvTox 1 is indicated by an arrow. B, Western blot analysis of expressed FvTox 1 proteins. Protein preparations from the whole Sf21 cell lysates carrying empty vector $(\mathrm{V})$, mature-FvTox $1(\mathrm{M})$, and pro-FvTox1 (P), along with proteins from cell-free $F v$ culture filtrates $(\mathrm{CF})$ were hybridized to the anti-FvTox 1 $7 \mathrm{E} 8$ monoclonal antibody. C, Western blot analysis of Sf21 insect cells expressing recombinant His-tagged pro-FvTox1 protein. In the left panel, whole cell proteins of Sf21 insect cells carrying empty vector (V) or His-tagged pro-FvTox 1 (P) were resolved in a $12 \%$ sodium dodecyl sulfate-PAGE gel and were detected by anti-FvTox1 antibody. In the right panel, His-tagged pro-FvTox1 (P) and His-tagged GmPUB1-1 protein (U) (as a positive control) were analyzed using the anti-His antibody. Note that cleavage of N-terminal His-tag resulted in failure of anti-His antibody to detect His-tagged pro-FvTox 1 protein. D, Location of cleavage sites in pro-FvTox1: site 1 (between two alanine residues) in Sf21 cells and site 2 (between arginine and serine residues) in Fusarium virguliforme grown in liquid medium. The N-terminal peptide sequences are underlined. E, FvTox 1 was excreted by Sf 21 cells into culture medium. Sf21 cells infected with either empty vector (V), pro-FvTox1 (P), or mature-FvTox1 (M). Sf21 cell cultures were harvested at 72 h postinoculation. Cell-free Sf21culture filtrates were used for Western blot analysis. 
for a possible chloroplast transit peptide (cTP) in FvTox1 revealed that the first 32 aa represent a cTP (CS score 3.25 [Emanuelsson et al. 1999]).

\section{Expressed FvTox1 proteins caused}

chlorosis and necrosis in soybean leaf disks.

The recombinant FvTox1 isolated from the baculovirusinfected insect cells (Fig. 5) were infiltrated into soybean leaf disks of the soybean cultivar Essex, susceptible to $F$. virguliforme. The typical chlorotic foliar SDS symptom was observed when leaf disks were infiltrated with expressed mature- and proFvTox 1 proteins (Fig. 5A). We then investigated if the chlorotic symptom induced by the FvTox1 proteins was associated with the susceptibility of soybean cultivars to $F$. virguliforme. Leaf disks of four SDS-resistant and four SDS-susceptible lines, including 'Essex', were vacuum-infiltrated with the recombinant FvTox1. Consistently, all four SDS-resistant cultivars showed tolerance to the expressed FvTox1. On the contrary, chlorosis was pronounced in leaf disks of the SDS-susceptible cultivars. Chlorophyll content was significantly reduced in the SDS-susceptible but not in the SDS-resistant soybean cultivars as com- pared with the control (Fig. 5B). Induction of chlorotic SDS symptoms in leaf disks of SDS-susceptible but not in SDS-resistant lines suggested that FvTox 1 identified in this investigation is most likely involved in foliar SDS development.

\section{FvTox1 is expressed in infected soybean roots.}

FvTox1 was purified from the culture filtrates. We investigated whether the FvToxl gene is expressed in F. virguliformeinfected soybean roots. Reverse transcription-polymerase chain reaction (RT-PCR) experiments showed that the gene is transcribed in infected soybean roots (Fig. 6B). Western analysis was conducted for detecting FvTox 1 in infected soybean roots. We, however, failed to detect FvTox 1 in infected roots of light-grown soybean plants. Instead, cross-reactivity of the antibody to multiple proteins was observed. Failure to detect the toxin in infected roots could have resulted from one or both of the following reasons: i) low levels of the infected tissues and FvTox1 peptide in the infected roots and ii) crossreactivity of the antibody to additional proteins. To increase the amounts of infected tissues and FvTox1 in infected roots, etiolated soybean seedlings were inoculated with conidial sus-

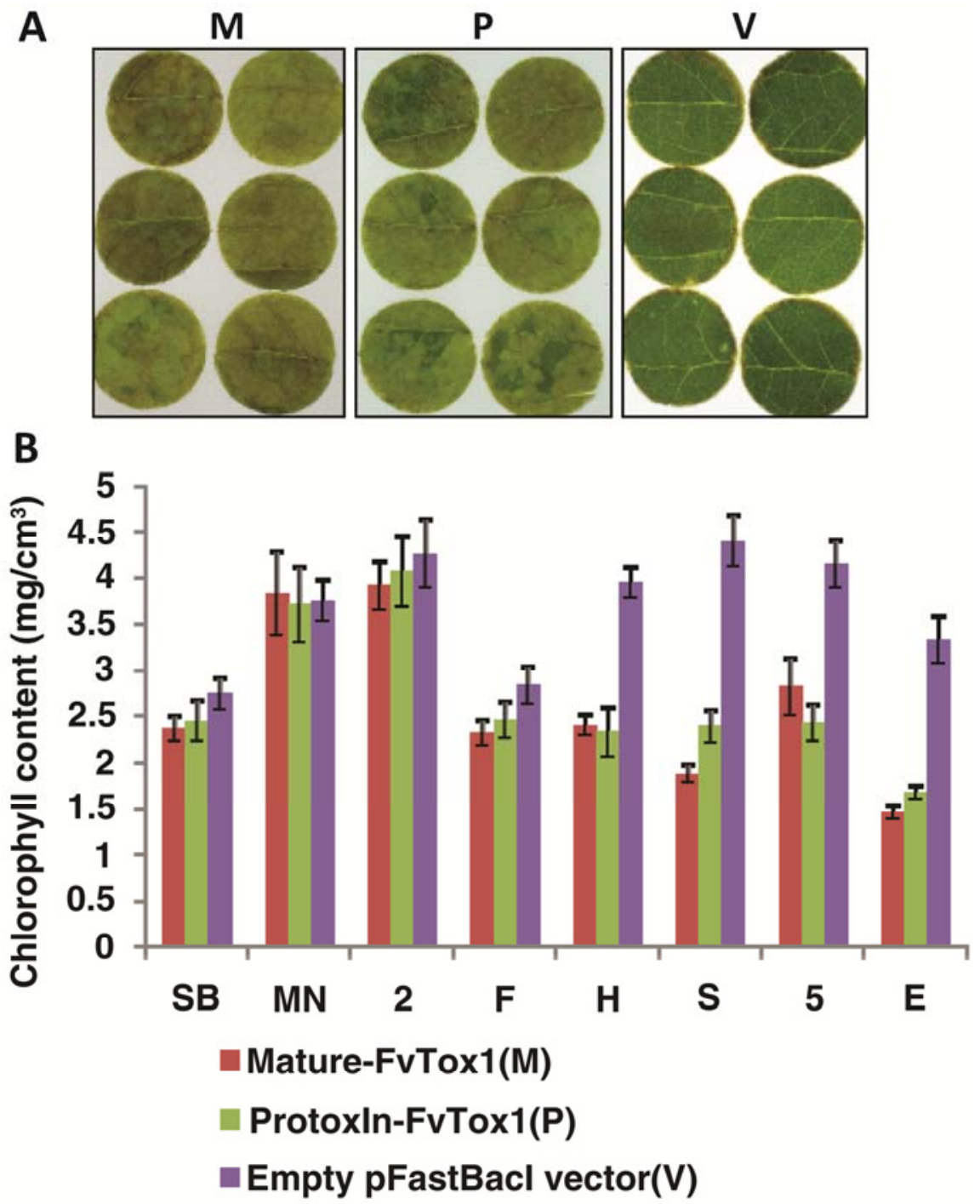

Fig. 5. Recombinant FvTox1 proteins cause loss of chlorophyll in soybean leaf disks. A, Loss of chlorophylls in a sudden death syndrome (SDS)-susceptible soybean line, 'Essex', infiltrated with protein preparations from Sf21 insect cell lines carrying either the empty pFastBac1vector (V), pro-FvTox1 (P), or mature-FvTox1 (M). B, Chlorophyll content in leaf disks of SDS-resistant (SB = SB2859R, MN = Mn-1606SP, $2=233+\mathrm{RR})$, partially SDS-resistant (F = Forrest), and SDS-susceptible $(\mathrm{H}=\mathrm{H} 2494, \mathrm{~S}=\mathrm{S} 03-007 \mathrm{CR}, 5=5171 \mathrm{RR}$, and $\mathrm{E}=\mathrm{Essex})$ soybean cultivars vacuum-infiltrated with protein preparations from Sf21 cells carrying either empty pFastBac1vector $(\mathrm{V})$, mature-FvTox1 $(\mathrm{M})$, or pro-FvTox1 $(\mathrm{P})$. Error bars represent standard error $(n-1=23)$. The assays were conducted three times. 
pensions. Visible root rot symptoms were seen in the inoculated seedlings (Fig. 6D). RT-PCR analyses confirmed the expression of the FvTox 1 gene in infected roots of etiolated seedlings (data not shown). A low-molecular-weight protein was detected by the anti-FvTox $17 \mathrm{E} 8$ monoclonal antibody in the infected but not in the uninfected roots (Fig. 6E). These results established that FvToxl is expressed in $F$. virguliformeinfected soybean roots.

\section{DISCUSSION}

FvTox1 causes foliar SDS-like symptoms in soybean.

$F$. virguliforme, causal pathogen of soybean SDS, has never been isolated from diseased foliar tissues. It has been speculated that one or more toxins released by the pathogen into the infected roots cause foliar SDS symptoms. The facultative fungal pathogen $F$. virguliforme also releases one or more toxins to the culture media. Recombinant FvTox 1 expressed in a baculovirus-infected insect cell line caused loss of chlorophylls as well as necrosis in soybean leaf disks. The loss of chlorophyll is a typical foliar SDS symptom. Cell-free $F$. virguliforme culture filtrates containing this toxin cause foliar SDS symptoms only in the presence of light (Ji et al. 2006). Similarly, FvTox1 isolated in this investigation can cause necrosis only in the presence of light (Supplementary Fig. S4). SDS-susceptible soybean cultivars, not the SDS-resistant cultivars, were highly sensitive to FvTox1 (Fig. 5). Thus, FvTox1 is most likely a major $F$. virguliforme pathogenicity factor involved in foliar SDS development in soybean.

$F$. virguliforme remains in infected soybean roots; and yet, it produces one or more toxins to cause foliar SDS. Presumably, the pathogen targets foliar tissues to reduce or eliminate the nutrient supply to roots so that it can completely overcome possible partial root resistance for successful establishment.

\section{Light is required \\ for FvTox1-induced foliar SDS symptom development.}

Induction of host cell-death machinery is one of the mechanisms used by pathogens to overcome plant defense systems. Toxins are shown to trigger programmed cell death (PCD) leading to large-scale chlorosis and necrosis (Rep 2005). For example, victorin, a cylicized pentapeptide toxin produced by Cochliobolus victoriae, induces a form of PCD in oats that is similar to apoptosis, characterized by DNA breakdown, shrinking cells, and activation of proteases (Wolpert et al. 2002). Sensitivity of Arabidopsis to victorin is mediated by a disease resistance (R)like protein containing nucleotide binding sites and a leucinerich region (NB-LRR) (Lorang et al. 2007). Similarity of molecular phenotypes induced by host-selective fungal toxins with those by avirulence factors in at least some plant-pathogen interactions and identification of an R-like victorin-interacting protein suggest similarities between molecular mechanisms used by toxins and avirulence factors in initiating disease symptoms (Lorang et al. 2007; Wolpert et al. 2002).

Victorin degrades Rubisco (Navarre and Wolpert 1999). Rubisco degradation affects the chloroplast electron transport chain leading to accumulation of reactive oxygen species (ROS) in the chloroplast. Ptr ToxA toxin, transferred horizontally from Stagonospora nodorum to Pyrenophora triticirepentis (Friesen et al. 2006), has been localized to the chloroplast and interacts with a chloroplast protein (Manning and Ciuffetti 2005; Manning et al. 2007). It induces ROS in a light-
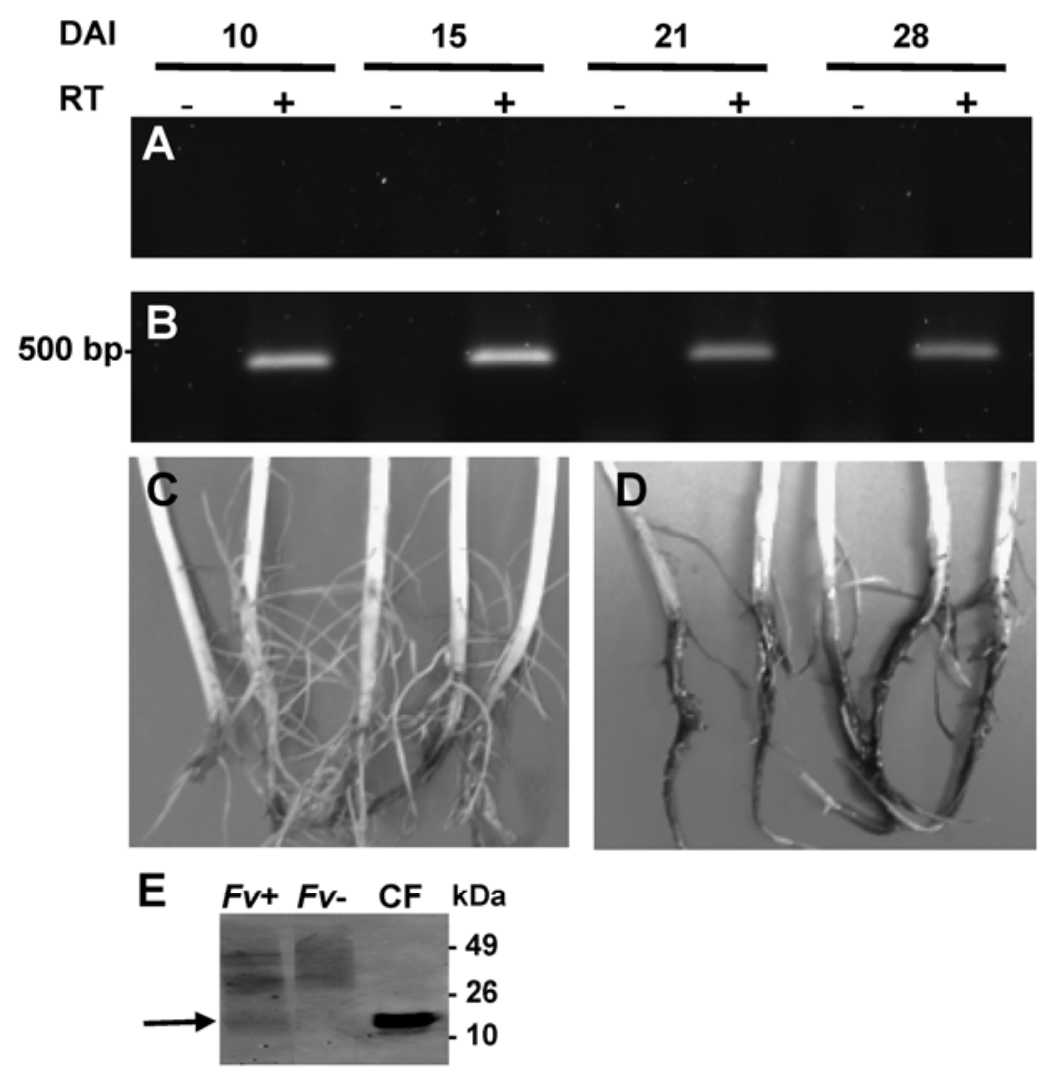

Fig. 6. Expression of FvTox1 in Fusarium virguliforme-infected soybean roots. A, Reverse transcription-polymerase chain reaction (RT-PCR) of uninfected, healthy soybean roots, collected on different days following sowing. B, RT-PCR of soybean roots infected with $F$. virguliforme at the time of sowing. Roots harvested on various days following sowing. C, Roots of healthy 7-day-old dark-grown soybean seedlings treated with water. D, Roots of 7-day-old dark-grown soybean infected with $F$. virguliforme conidia for 7 days. E, Western blot analysis of proteins extracted from roots of dark-grown seedlings either infected with $F$. virguliforme conidia $(F v+)$ or treated with water $(F v-) . \mathrm{CF}=$ cell-free $F$. virguliforme culture filtrate. The candidate FvTox1-specific band is indicated by an arrow. 
dependent manner and degrades Rubisco and brings changes to photosystems I and II (Manning et al. 2009). Under abiotic stress conditions, chloroplasts produce ROS (Doyle et al. 2010; Mullineaux and Karpinski 2002). The ROS production in chloroplast has been shown to cause PCD in tobacco and Arabidopsis (Chen and Dickman 2004; Doyle et al. 2010).

FvTox 1 is predicted to have a cTP (Fig. 4). F. virguliforme culture filtrates containing FvTox1 were also shown to degrade Rubisco large subunit and produce ROS in a light-dependent manner (Ji et al. 2006). Light is also essential for necrosis development by FvTox1. We speculate that FvTox1 may use a mechanism similar to the ones used by victorin and Ptr ToxA and degrades Rubisco to produce ROS for initiating foliar SDS-like symptoms.

\section{Expression of anti-FvTox1 antibody may enhance foliar SDS resistance.}

Many host-selective fungal toxins are mobile and cause disease symptoms at a distance far from the infection site (Walton 1996). Following release of FvTox 1 by the fungus to the roots, most likely it is transported through the vascular system to the leaves, in which it causes foliar SDS. Sensitivity of SDS-susceptible but not SDS-resistant soybean cultivars to FvTox1 (Fig. 5) suggested that FvTox1 functions in a cultivar-specific manner, and therefore, it is most likely a major pathogenicity or virulence factor for foliar SDS development. Foliar SDS is the major reason for yield reduction in $F$. virguliforme-infected SDS-susceptible soybeans lines. It is possible that the functional plant anti-FvTox 1 antibody expressed in stable transgenic soybean lines may bind to FvTox1 before it can cause damage to foliar tissues. Such lines will then have enhanced tolerance to foliar SDS and increased seed yield as compared with the control plants.

\section{MATERIALS AND METHODS}

\section{Preparation of cell-free $\boldsymbol{F}$. virguliforme culture filtrates.}

F. virguliforme isolate Clinton $1 \mathrm{~B}$ was grown on solid Bilay medium $\left(0.1 \% \quad \mathrm{KH}_{2} \mathrm{PO}_{4}\right.$ [wt/vol], $0.1 \% \quad \mathrm{KNO}_{3}$ [wt/vol], $0.05 \%$ $\mathrm{MgSO}_{4}$ [wt/vol], $0.05 \% \mathrm{KCl}$ [wt/vol], $0.02 \%$ starch [wt/vol], $0.02 \%$ glucose [wt/vol], and $0.02 \%$ sucrose [wt/vol]). Forty plugs were transferred from the plate to $100 \mathrm{ml}$ of liquid modified Septoria medium (MSM) and were incubated at room temperature for 12 days in the dark without shaking. The liquid was passed through two layers of Whatman no. 1 filter paper, and $\mathrm{pH}$ was adjusted to 6.0 with $\mathrm{HCl}$. The liquid was again passed first through $0.45-\mu \mathrm{m}$ and then $0.22-\mu \mathrm{m}$ Stericups (Millipore, Inc., Bedford, MA, U.S.A.). The cell-free $F$. virguliforme culture filtrates were used in stem-cutting assays or Western blot analysis or were stored at $-20^{\circ} \mathrm{C}$ until further use ( $\mathrm{Li}$ et al. 1999).

\section{Gel filtration.}

Gel filtration of the cell-free $F$. virguliforme culture filtrates was carried out in an approximately 30-cm-long Sephacryl S300HR column (Sigma-Aldrich, St. Louis). The range of separation of this matrix was 10 - to $1,500-\mathrm{kDa}$ proteins. For elution of the proteins, $50 \mathrm{mM}$ Tris- $\mathrm{HCl}, \mathrm{pH} 5.5$, was used. About $3 \mathrm{mg}$ of proteins were loaded in each run and approximately $1-\mathrm{ml}$ fractions were manually collected. Protein was quatified using a colorimetric assay based on binding to Bradford dye (Bio-Rad, Hercules, CA, U.S.A.). Bovine serum albumin dilutions were used for standardizing the protein concentrations.

\section{Stem-cutting assay.}

Seeds of the cultivar Williams 82 were provided by R. Nelson, University of Illinois (Urbana, IL, U.S.A.), and were grown in a growth chamber under light at $25^{\circ} \mathrm{C}$ for $16 \mathrm{~h}$ and in the dark at $16^{\circ} \mathrm{C}$ for $8 \mathrm{~h}$. The light intensity was $200 \mu \mathrm{mol}$ photons $\mathrm{m}^{-2} \mathrm{~s}^{-1}$. Three-week-old seedlings were cut below the cotyledons and were used for bioassays. Cut seedlings were placed into tubes containing $20 \mathrm{ml}$ of the test solutions. Crude cell-free $F$. virguliforme culture filtrates, column fractions, or eluted protein samples from polyacrylamide gels were diluted in autoclaved, double-distilled water for conducting stem-cutting assays. For testing the phytotoxic activity of column fractions, $500 \mu \mathrm{l}$ of eluate from each fraction were diluted to a final volume of $20 \mathrm{ml}$ with autoclaved, double-distilled water. Water, diluted MSM, and $50 \mathrm{mM}$ Tris- $\mathrm{HCl}, \mathrm{pH} 5.5$, were used as controls. Symptoms appeared 7 to 8 days following the feeding of the $F$. virguliforme culture filtrates. The scoring scheme was similar to the one used by $\mathrm{Ji}$ and associates (2006): 0 , no symptoms; $1,<10 \%$ chlorosis; 2,10 to $20 \%$ chlorosis; 3, 20-50\% chlorosis; 4, 50 to $80 \%$ chlorosis and necrosis; 5 , entire leaf was chlorotic or necrotic.

\section{Protein fractionation in native polyacrylamide gels.}

Lyophilized cell-free $F$. virguliforme culture filtrates were dissolved in autoclaved, double-distilled water and were then mixed with $2 \times$ loading buffer ( $0.1 \mathrm{M}$ Tris [pH 6.8], $20 \%$ glycerol [vol/vol], $0.1 \%$ bromophenol blue [wt/vol]). A 50- $\mu$ l sample was separated in 12 or $14 \%$ native polyacrylamide gels (vol/vol) carrying no sodium dodecyl sulfate in running buffer $(25 \mathrm{mM}$ Tris [wt/vol], $192 \mathrm{mM}$ glycine [wt/vol], pH 7.5) . Bio-Rad precision plus protein marker was used (Bio-Rad) in estimating the molecular size of proteins. Gels were run at $110 \mathrm{~V}$ for $5 \mathrm{~h}$ in a Bio-Rad Protean II system (Bio-Rad). The gels were divided into three longitudinal sections (Fig. 2). The two outer longitudinal sections of about 3 to $4 \mathrm{~cm}$ were fixed, stained (45\% metha$\mathrm{nol}[\mathrm{vol} / \mathrm{vol}]+10 \%$ glacial acetic acid $[\mathrm{vol} / \mathrm{vol}]+0.5 \%$ Coomassie brilliant blue G-250 [wt/vol]), and destained (30\% methanol $[\mathrm{vol} / \mathrm{vol}]+10 \%$ glacial acetic acid [ $\mathrm{vol} / \mathrm{vol}])$ to visualize the protein profiles. Stained gel slices were aligned with the large unstained middle longitudinal gel section. The middle unstained gel section was dissected into six horizontal gel slices (Fig. 2A), and proteins from each slice were extracted as follows. Gel slices were ground into very small pieces and mixed with autoclaved, double-distilled water to a final volume of $15 \mathrm{ml}$ in Falcon tubes and were vortexed at maximum speed for $2 \mathrm{~min}$. The tubes were stored at $-20^{\circ} \mathrm{C}$ overnight. The following day, the tubes were thawed and centrifuged at 3,000 rpm for $20 \mathrm{~min}$. The supernatant was filtered through a layer of Whatman no. 1 filter paper, and the eluents were diluted in autoclaved, double-distilled water for stem-cutting assays.

\section{Generation of anti-FvTox1 monoclonal antibodies.}

The putative FvTox 1 protein in gel slices from native polyacrylamide gel electrophoresis (PAGE) was injected into four mice of the Balb/c line at the Iowa State University Hybridoma Facility (Ames, IA, U.S.A.). After two weeks, another injection was given to boost the antibody production. Two weeks after the second injection, blood was drawn from the mice and serum was separated by using a serum gel-clotting activator column (Sarstedt Inc. Newton, NC, U.S.A.). Sera were tested for antibody titer, first by ELISA and, then, by Western blot analyses. The sera from four mice were tested for cross-reactivity to FvTox 1 in Western blot analyses. The mouse showing the strongest anti-FvTox1 antibody reaction to FvTox1 was sacrificed, and its spleen was dissected. The splenocytes were fused to mouse myeloma cells (SP2/0) to generate hybridoma cells (Yokoyama et al. 2006). The hybridoma clones were tested by conducting ELISA for cross reactivity to FvTox1. ELISA positive clones were tested for cross reactivity to FvTox1 in Western blot analyses. 


\section{Western blot analyses.}

Protein content was determined by colorimetric assay, based on binding to Bradford dye (Bio-Rad). Bovine serum albumin dilutions were used for standardizing the protein concentrations. Equal amounts of proteins from each sample were separated on denaturing PAGE gels. The gels were blotted onto Optitran nitrocellulose membrane (Midwest Scientific, St. Louis). The membranes were hybridized to either anti-FvTox 1 monoclonal antibody or anti-His tag antibody (Sigma-Aldrich). Hybridization was detected using goat anti-mouse antibody conjugated to alkaline phosphatase (Bio-Rad).

\section{Immuno-suppression of the phytotoxic activity of $F$. virguliforme culture filtrates.}

Concentrated cell-free $F$. virguliforme culture filtrates containing about $100 \mu \mathrm{g}$ of proteins were incubated with 500, 300, or $100 \mu \mathrm{l}$ of anti-FvTox 1 monoclonal antibody in $0.6 \times$ phosphate buffered saline (PBS; $4.8 \% \mathrm{NaCl}$ [wt/vol], $0.12 \% \mathrm{KCl}$ [wt/vol], $0.144 \% \mathrm{KH}_{2} \mathrm{PO}_{4}$ [wt/vol], $0.864 \% \mathrm{Na}_{2} \mathrm{HPO}_{4}$ [wt/vol]), $\mathrm{pH} 7.4$, for $6 \mathrm{~h}$ at $4^{\circ} \mathrm{C}$, with shaking. Tubes were centrifuged at $4,000 \times g$ for $3 \mathrm{~min}$. Supernatant was used for the stem-cutting assays.

\section{Construction and screening of an expression cDNA library.}

Total RNA was extracted from $F$. virguliforme mycelia grown for 10, 11, 12, 13, and 14 days in MSM liquid medium. Poly $\left(\mathrm{A}^{+}\right)$RNA was isolated from total RNAs using PolyATract mRNA isolation system IV (Promega, Madison, WI, U.S.A.). An expression $F$. virguliforme cDNA library for mycelia was constructed in $\lambda$ TriplEx2 (Clontech, Mountain View, CA, U.S.A.) was provided by W. A. Moskal, The Institute of Genomic Research (Rockville, MD, U.S.A.). The $\lambda$ TriplEx2 expression library was screened using a mixture of all four antFvTox 1 monoclonal antibodies, following the Clontech protocol. About 500,000 plaque-forming units were screened. The positive plaques were rescreened. By infecting Escherichia coli BM25.8 with pure phage particles, $\lambda$ TriplEx 2 particles were excised into pTriplEx2 plasmids, according to the Clontech protocol (Clontech). E. coli BM25.8 carrying individual putative cDNA plasmids was grown overnight in $2 \mathrm{ml}$ of super optimal broth (SOB) medium containing ampicillin at $37^{\circ} \mathrm{C}$, with shaking. The following day, $25 \mathrm{ml}$ of SOB medium was inoculated with the overnight culture to an optical density at $600 \mathrm{~nm}$ $\left(\mathrm{OD}_{600}\right)$ of 0.1 and was grown at $37^{\circ} \mathrm{C}$ to an $\mathrm{OD}_{600}$ of 0.4 to 0.6. A 1-ml aliquot from each culture was centrifuged, and the pellet was stored at $-20^{\circ} \mathrm{C}$ until further use. To the rest of the culture, isopropyl- $\beta$-D-thiogalactoside was added to a final concentration of $1 \mathrm{mM}$, and cultures were grown at $37^{\circ} \mathrm{C}$ for $4 \mathrm{~h}$. Aliquots of 1 $\mathrm{ml}$ were taken every hour and were centrifuged, and pellets were stored at $-20^{\circ} \mathrm{C}$ until used. Cell pellets were resuspended in 100 $\mu \mathrm{l}$ of $20 \mathrm{mM}$ PBS, $\mathrm{pH}$ 7. The mixture was frozen in liquid nitrogen and was then thawed at $42^{\circ} \mathrm{C}$. Freeze-thaw was repeated four times. The tubes were centrifuged at 13,000 rpm for $10 \mathrm{~min}$ at $4{ }^{\circ} \mathrm{C}$. The supernatant was transferred into a new Eppendorf tube, and the pellet was resuspended in $100 \mu \mathrm{l}$ of $2 \times$ sodium dodecyl sulfate sample buffer (0.1 M Tris [pH 6.8], 2\% sodium dodecyl sulfate, $20 \%$ glycerol [vol/vol], $2 \% \beta$-mercapto ethanol [vol/vol], $0.1 \%$ bromophenol blue [wt/vol]) and was boiled for 5 min and, then, resolved in a sodium dodecyl sulfate-PAGE gel. The supernatant was mixed with $100 \mu \mathrm{l}$ of $2 \times$ loading buffer and was separated in a native-PAGE gel and denaturing PAGE gels. A $50-\mu$ sample was separated in 12 or $14 \%$ native polyacrylamide gels ( $\mathrm{vol} / \mathrm{vol}$ ) carrying no sodium dodecyl sulfate in running buffer (25 mM Tris [wt/vol], $192 \mathrm{mM}$ glycine [wt/vol], $\mathrm{pH}$ 7.5). Western blot analyses were conducted using all four antiFvTox1 monoclonal antibodies. cDNA inserts of positive pTriplEx 2 clones were sequenced.
Genomic library screening.

DNA was isolated from $F$. virguliforme mycelia grown for $10,11,12,13$, and 14 days in MSM liquid medium using the cetyl trimethylammonium bromide method. A genomic library was constructed in lambdaFixII vector (Stratagene, La Jolla, CA, U.S.A.). The library was screened using an FvTox 1 cDNA molecule radiolabeled with $\alpha-{ }^{32} \mathrm{P}$ as described in the next section. Purified genomic clones were PCR-amplified using primers specific to the FvToxl cDNA molecule (FvTF-ATG AAGTCCACATTCACCCTTG and FvTR-GCGCTGTGGGT TGCGCACACAGTTG).

\section{Gel electrophoresis and Southern hybridization.}

Approximately $5 \mu \mathrm{g}$ of DNA was incubated overnight at $37^{\circ} \mathrm{C}$ with individual restriction enzymes (New England Biolabs, Beverly, MA, U.S.A.). The digested DNA samples were electrophoresed on $0.8 \%$ agarose gels (wt/vol). The DNA was then transferred onto Zeta-Probe GT membrane (BioRad), using the capillary action of $0.4 \mathrm{~N} \mathrm{NaOH}$ and $1.5 \mathrm{M}$ $\mathrm{NaCl}$ solution. The filters were neutralized in $100 \mathrm{mM}$ Tris$\mathrm{HCl}, \mathrm{pH} 7.5$, for $5 \mathrm{~min}$ and were washed twice in $2 \times \mathrm{SSC}$ ( $1 \times \mathrm{SSC}$ is $0.15 \mathrm{M} \mathrm{NaCl}$ plus $0.015 \mathrm{M}$ sodium citrate) for 5 min each. The filters were air dried and were baked between two sheets of Whatman no. $3 \mathrm{MM}$ paper for $2 \mathrm{~h}$ at $80^{\circ} \mathrm{C}$. DNA filters were prehybridized in $6 \times$ SSC buffer (Maniatis et al. 1982) containing $0.5 \%$ sodium dodecyl sulfate (wt/vol), $5 \times$ Denhardt's solution, and denatured salmon sperm DNA $(200 \mu \mathrm{g} / \mathrm{m})$ (Sigma-Aldrich) for $2 \mathrm{~h}$ at $45^{\circ} \mathrm{C}$. $\left[{ }^{32} \mathrm{P}\right] \mathrm{ATP}-$ labeled (PerkinElmer, Waltham, MA, U.S.A.) cDNA molecules were prepared according to Feinberg and Vogelstein (1983). Unincorporated nucleotides were removed from the radio-labeled probes using a Sephadex G-50 column (Bio$\mathrm{Rad})$. The prehybridization buffer was replaced with the purified ${ }^{32} \mathrm{P}$-labeled probe in fresh $6 \times \mathrm{SSC}$ buffer and was hybridized to the DNA filters for $16 \mathrm{~h}$ at $45^{\circ} \mathrm{C}$. After $16 \mathrm{~h}$, the filters were washed with $6 \times \mathrm{SSC}$ and $0.5 \%$ sodium dodecyl sulfate (wt/vol) for $30 \mathrm{~min}$ at $45^{\circ} \mathrm{C}$, and then, with $3 \times \mathrm{SSC}$ and $0.5 \%$ sodium dodecyl sulfate (wt/vol) for $45 \mathrm{~min}$ at $45^{\circ} \mathrm{C}$, and finally, with $2 \times \mathrm{SSC}$ and $0.5 \%$ sodium dodecyl sulfate $(\mathrm{wt} / \mathrm{vol})$ for $45 \mathrm{~min}$ at $45^{\circ} \mathrm{C}$. The filters were then wrapped in between two Saran Wrap pieces and were exposed to X-ray films overnight at $-80^{\circ} \mathrm{C}$.

\section{FvTox1 expression in insect cells.}

Sf21 cells derived from the fall armyworm Spodoptera frugiperda were maintained in TC-100 insect-cell medium (Sigma-Aldrich) supplemented with fetal bovine serum (Invitrogen, Carlsbad, CA, U.S.A.) to a final concentration of $10 \%$ and antibiotics (wt/vol) (1 U of penicillin per milliliter, $1 \mathrm{mg}$ of streptomycin per milliliter; [Sigma]). The cell cultures were maintained at $28^{\circ} \mathrm{C}$ as monolayers in screw-capped plastic flasks (Fisher Scientific, Pittsburgh, PA, U.S.A.). Pro-FvTox1 and mature-FvTox 1 were PCR-amplified and cloned into the bacmid transfer vector, pFastBac1 (Invitrogen, Carlsbad, CA, U.S.A.). Transfer vector carrying either of the FvToxl genes was used to make recombinant bacmids by following the Bacto-Bac Baculovirus expression system protocol (Invitrogen). Sf21 cells were transfected with the recombinant bacmids to produce recombinant baculoviruses carrying FvToxl sequences or only empty pFastBac1 vector. Baculovirus expresses recombinant proteins from the polyhedrin promoter. Cells were harvested at $72 \mathrm{~h}$ postinfection and were pelleted and resuspended in $1 \times$ sodium dodecyl sulfate-PAGE sample buffer. Aliquots $(50,000$ cell equivalents) of the cell extracts were run on $12 \%$ sodium dodecyl sulfate polyacrylamide gels (wt/vol). Gels were stained with Coomassie blue G-250 for visualization of proteins. 


\section{Leaf disk assay.}

Seeds of various soybean cultivars (SB2859R, Mn-1606SP, 233+RR, Forrest, H2494, S03-007CR, 5171RR, Essex), were grown in a growth chamber under light at $25^{\circ} \mathrm{C}$ for $16 \mathrm{~h}$ and in the dark at $16^{\circ} \mathrm{C}$ for $8 \mathrm{~h}$. The light intensity was $200 \mu \mathrm{mol}$ photons $\mathrm{m}^{-2} \mathrm{~s}^{-1}$. Unifoliates were harvested from 17- to 20-dayold seedlings, and leaf disks were prepared using the open edge of a 15-ml tube. The recombinant proteins and the culture filtrate were diluted to 1:5 in autoclaved, double-distilled water (unless otherwise mentioned). The test solutions were added to a 50-ml tube and eight leaf disks were added to each. The wider edge of a pasture pipette was placed on the leaf disks to keep leaf disks in the test solution. The leaf disks were vacuum-infiltrated with the test solutions. The leaf disks were then placed on petri plates with $3 \mathrm{ml}$ of test solution and were incubated under continuous light $\left(30 \mu \mathrm{mol}\right.$ photons $\left.\mathrm{m}^{-2} \mathrm{~s}^{-1}\right)$ conditions. The following day, additional water $(5 \mathrm{ml})$ was added to each petri plate, to keep the leaf disks moist. The leaf disks were photographed 4 days after infiltration.

\section{Mass spectrometry analysis.}

To confirm the identity of FvTox 1 expressed in insect cells, tandem mass spectrometry (MS/MS) analysis of pro-FvTox1 and the purified toxin from $F$. virguliforme culture filtrates was conducted as follows. The protein bands of a $12 \%$ sodium dodecyl sulfate polyacrylamide gel (wt/vol) stained with $45 \%$ methanol (vol/vol), $10 \%$ glacial acetic acid (vol/vol), and $0.5 \%$ Coomassie brilliant blue G-250 (wt/vol) were precisely excised and were subjected to tryptic digestion for matrix-assisted laser desorption-ionization (MALDI)-MS/MS analyses. MALDI-time of flight (TOF) MS/MS analyses were performed using a QSTAR XL quadrupole TOF mass spectrometer (AB/MDS Sciex, Toronto, Canada) equipped with an oMALDI ion source at the Iowa State University Proteomic Facility. All spectra were processed by MASCOT (MatrixScience, London) database search. Peak lists were generated by Analyst QS (AB/MDS Sciex) and were used for MS/MS ion searches.

\section{N-terminal sequencing.}

Following the transfer of proteins onto a Hybond-P polyvinylidene diflouride (PVDF) membrane, the membrane was stained with $0.1 \%$ Coomassie blue G-250 (wt/vol) and was destained with $50 \%$ methanol (vol/vol) several times, until proteins were visible and background was clear. The membrane was then washed six times with autoclaved, double-distilled water, and the proteins were precisely excised from the PVDF membrane and were sequenced by the Edman degradation method in a 494 Procise protein sequencer/140C analyzer (Applied Biosystems, Inc., Foster City, CA, U.S.A.) at the Iowa State University Protein Facility.

\section{Measurement of chlorophyll content.}

Soybean leaf disks infiltrated with protein preparations were placed individually in Eppendorf tubes and were frozen overnight at $-80^{\circ} \mathrm{C}$. The next day, $1 \mathrm{ml}$ of $80 \%$ acetone was added to each tube, and the tubes were incubated at room temperature in the dark for 5 days. Absorbance of the acetone solution containing chlorophylls was measured at 645 and $663 \mathrm{~nm}$. The amount of chlorophylls was calculated essentially according to the method described by Arnon (1949).

\section{Inoculation of seedlings with $\boldsymbol{F}$. virguliforme.}

Soybean seeds were grown in a 1:1 mixture of sand and soil containing $F$. virguliforme grown on sorghum seeds according to Mueller and associates (2002). Control plants were grown only in sand and soil mixture. The roots from infected and control plants were collected and were used for RNA prepara- tion. Etiolated seedlings were grown in the dark for 7 days at $22^{\circ} \mathrm{C}$ in coarse vermiculite. Ten etiolated seedlings were placed in a tube containing $20 \mathrm{ml}$ of $F$. virguliforme conidial suspensions $\left(2 \times 10^{6}\right.$ per milliliter $)$. Control seedlings were placed in $10 \mathrm{ml}$ of autoclaved, double-distilled water. Roots were harvested 7 days after infection or treatment with autoclaved, double-distilled water and were stored at $-80^{\circ} \mathrm{C}$. The experiments were conducted at least three times. For protein preparation, the frozen samples were ground in buffer containing $5 \mathrm{mM}$ EDTA, $100 \mathrm{mM}$ potassium phosphate, $1 \%$ Triton (vol/vol), $10 \%$ glycerol (vol/vol), and proteinase inhibitor cocktail $(1 \mu \mathrm{l} / \mathrm{ml})$ (Sigma-Aldrich). The resulting slurry was centrifuged at $12,000 \mathrm{rpm}$ at $4^{\circ} \mathrm{C}$. The supernatant was mixed with $4 \times$ sodium dodecyl sulphate loading dye, and was separated in a $12 \%$ polyacrylamide gel ( $\mathrm{vol} / \mathrm{vol})$. The gel was blotted overnight onto a nitrocellulose membrane (Midwest Scientific, St. Louis), and Western blot analysis was conducted using antiFvTox1 7E8 monoclonal antibody.

\section{RNA preparation and RT-PCR.}

For each time interval, three plants were sampled. RNAs were prepared using Trizol (Invitrogen). RNAs were treated with DNAse (Invitrogen), and the first strand cDNAs were synthesized using Superscript II reverse transcriptase (Invitrogen). cDNAs were used as templates for PCR. The forward primer (FvToxExoF-CACGCTGGAATGGTCTACTTTTG) for PCR was designed around the junction sequence between the $3^{\prime}$ end of the first exon and the $5^{\prime}$ end of the second exon. The reverse primer (FvToxExoR-GGGCGCTGAGTGTTGCCATC) was designed around the junction sequence at the $3^{\prime}$ end of the second exon and the $5^{\prime}$ end of the third exon. The primers were expected to amplify a fragment of 173 bp only from cDNAs but not from contaminating genomic DNA. First-strand synthesis was conducted at $42^{\circ} \mathrm{C}$ and second-strand synthesis was done at $66^{\circ} \mathrm{C}$. PCR was done for 30 cycles $\left(94^{\circ} \mathrm{C}\right.$ for 2 min once, 30 cycles at $94^{\circ} \mathrm{C}$ for $30 \mathrm{~s}, 55^{\circ} \mathrm{C}$ for $30 \mathrm{~s}$, and $72^{\circ} \mathrm{C}$ for $2 \mathrm{~min}$ ).

\section{ACKNOWLEDGMENTS}

We thank W. A. Moskal, The Institute of Genomic Research for kindly providing us with the $F$. virguliforme cDNA expression library. We thank S. Luo, Proteomics Facility, and J. D. Nott, Protein Facility, Iowa State University, for sequencing the proteins, M. D. Baker, DNA Facility, Iowa State University, for sequencing the $F$. virguliforme genome, and P. A. Kapke, Hybridoma Facility, Iowa State University, for raising the antibodies. We thank B. Diers and R. Nelson, University of Illinois, for kindly sending the soybean seeds. We thank H. Horner, and E. Yu, Iowa State University, and R. Shoemaker, United States Department of AgricultureAgricultural Research Service, and S. Muench, United Soybean Board, for critically reviewing the manuscript.

\section{LITERATURE CITED}

Abeysekara, N. S., Friesen, T. L., Keller, B., and Faris, J. D. 2009. Identification and characterization of a novel host-toxin interaction on the wheat-Stagonospora nodorum pathotype. Theor. Appl. Genet. 120:117126.

Aoki, T., O’Donnell, K., Homma, Y., and Lattanzi, A. R. 2003. Sudden death syndrome of soybean is caused by two morphologically and phylogenetically distinct species within the Fusarium solani species complex-F. virguliforme in North America and F. tucumaniae in South America. Mycologia 95:660-684.

Arnon, D. I. 1949. Copper enzymes in isolated chlorophlasts and polyphenol oxidase in Beta vulgaris. Plant Physiol. 24:1-15.

Bailey, B. A. 1995. Purification of a protein from culture filtrates of Fusarium oxysporium that induces ethylene and necrosis in leaves of Erythroxylum coca. Phytopathology 85:1250-1255.

Ballance, G. M., Lamari, L., and Bernier, C. C. 1989. Purification and characterization of a host-selective necrosis toxin from Pyrenophora tritici-repentis. Physiol. Mol. Plant Pathol. 35:203-213.

Bendtsen, J. D., Nielsen, H., von Heijne, G., and Brunak, S. 2004 
Improved Prediction of Signal Peptides: SignalP 3.0. J. Mol. Biol. 340:783-795.

Chen, S., and Dickman, M. B. 2004. Bcl-2 family members localize to tobacco chloroplasts and inhibit programmed cell death induced by chloroplast-targeted herbicides. J. Exp. Bot. 55:2617-2623.

Creppy, E. E. 2002. Update of survey, regulation and toxic effects of mycotoxins in Europe. Toxicol. Lett. 127:19-28.

Desjardins, A. E., and Hohn, T. M. 1997. Mycotoxins in plant pathogenesis. Mol. Plant-Microbe Interact. 2:147-152.

Doyle, S. M., Diamond, M., and McCabe, P. F. 2010. Chloroplast and reactive oxygen species involvement in apoptotic-like programmed cell death in Arabidopsis suspension cultures. J. Exp. Bot. 61:473482

Emanuelsson, O, Nielsen, H, and von Heijne G. 1999. ChloroP, a neural network-based method for predicting chloroplast transit peptides and their cleavage sites. Protein Sci. 8:978-984.

Feinberg, A. P. and Vogelstein, B. 1983. A technique for radiolabeling DNA restriction endonuclease fragments to high specific activity. Anal. Biochem. 132:6-13.

Friesen, T. L., Stukenbrock, E. H., Liu, Z., Meinhardt, S., Ling, H., Faris, J. D., Rasmussen, J. B., Solomon, P. S., McDonald, B. A., and Oliver, R. P. 2006. Emergence of a new disease as a result of interspecific virulence gene transfer. Nat. Genet. 38:953-956.

Friesen, T. L., Meinhardt, S. W., and Faris, J. D. 2007. The Stagonospora nodorum-wheat pathosystem involves multiple proteinaceous hostselective toxins and corresponding host sensitivity genes that interact in an inverse gene-for-gene manner. Plant J. 51:681-692.

Friesen, T. L., Faris, J. D., Solomon, P. S., and Oliver, R. P. 2008. Hostspecific toxins: Effectors of necrotrophic pathogenicity. Cell. Microbiol. 10:1421-1428

Hershman, D. E. 1990. Soybean sudden death syndrome in Kentucky. Page 37 in: University of Kentucky Cooperative Extension Service Information Bulletin No. PPA-37. University of Kentucky College of Agriculture, Lexington, KY, U.S.A

Hirrel, M. C. 1987. Sudden death syndrome of soybean: New insight into its development. Pages 95-104 in: Proceedings of Soybean Seed Conference, 16th Soybean Research Conference, December 9-10, 1986, Chicago. American Seed Trade Association, Alexandria, VA, U.S.A

Hnetkovsky, N. S., Chang, J. C., Doubler, D. W., Gibson, P. T., and Lightfoot, D. A. 1996. Genetic mapping of loci underlying field resistance to soybean sudden death syndrome (SDS). Crop Sci. 36:393-400.

Ji, J., Scott, M. P., and Bhattacharyya, M. K. 2006. Light is essential for degradation of ribulose-1,5-bisphosphate carboxylase-oxygenase large subunit during sudden death syndrome development in soybean. Plant Biol. 8:597-605.

Jin, H., Hartman, G. L., Nickell, C. D., and Widholm, J. M. 1996. Characterization and purification of a phytotoxin produced by Fusarium solani, the causal agent of soybean sudden death syndrome. Phytopathology 86:277-282.

Kazi, S., Shultz, J., Afzal, J., Johnson, J., Njiti, V., and Lightfoot, D. 2008. Separate loci underlie resistance to root infection and leaf scorch during soybean sudden death syndrome. Theor. Appl. Genet. 116:967-977.

Li, S., Hartman, G. L., and Widholm, J. M. 1999. Viability staining of soybean suspension cultured cells and a stem-cutting assay to evaluate phytotoxicity of Fusarium solani f. sp. glycines culture filtrates. Plant Cell Rep. 18:375-380

Lorang, J. M., Sweat, T. A., and Wolpert, T. J. 2007. Plant disease susceptibility conferred by a "resistance" gene. Proc. Natl. Acad. Sci. U.S.A. 104:14861-14866

Lui, Z. H., Faris, J. D., Meinhardt, S. W., Ali, S., , Rasmussen, J. B., and Friesen, T. L. 2004. Genetic and physical mapping of a gene conditioning sensitivity in wheat to a partially purified host-selective toxin produced by Stagonospora nodorum. Phytopathology 94:1056-1060.

Malvick, D. 2006. Sudden death syndrome (SDS) of soybean: Bridging experiences from Illinois to Minnesota. University of Minnesota Department of Agronomy and Plant Genetics, University of Minnesota, St. Paul, MN, U.S.A.

Maniatis, T., Fritsch, E. F., and Sambrook, J. 1982. Molecular Cloning: A Laboratory Manual. Cold Spring Harbor Laboratory, Cold Spring Harbor, NY, U.S.A.

Manning, V. A., and Ciuffetti, L. M. 2005. Localization of Ptr ToxA produced by Pyrenophora tritici-repentis reveals protein import into wheat mesophyll cells. Plant Cell 17:3203-3212.

Manning, V. A., Hardison, L. K., and Ciuffetti, L. M. 2007. Ptr ToxA interacts with a chloroplast-localized protein. Mol. Plant-Microbe. Interact. 20:168-177.

Manning, V. A., Chu, A. L., Steeves, J. E., Wolpert, T. J., and Ciuffetti, L. M. 2009. A host-selective toxin of Pyrenophora tritici-repentis, Ptr ToxA, induces photosystem changes and reactive oxygen species accumulation in sensitive wheat. Mol. Plant-Microbe. Interact. 22:665-676.

Martinez, J. P., Ottum, S. A., Ali, S., Francl, L. J., and Ciuffetti, L. M. 2001. Characterization of the ToxB gene from Pyrenophora triticirepentis. Mol. Plant-Microbe. Interact. 14:675-677.

Mueller, D. S., Hartman, G. L., Nelson, R. L., and Pedersen, W. L. 2002. Evaluation of Glycine max germ plasm for resistance to Fusarium solani f. sp. glycines. Plant Dis. 86:741-746.

Mullineaux, P., and Karpinski, S. 2002. Signal transduction in response to excess light: Getting out of the chloroplast. Curr. Opin. Plant Biol. 5:43-48.

Navarre, D. A., and Wolpert, T. J. 1999. Victorin induction of an apoptotic/senescence-like response in oats. Plant Cell 11:237-250.

O'Donnell, K. 2000. Molecular phylogeny of the Nectria haematococcaFusarium solani species complex. Mycologia 92:919-938.

O'Donnell, K., Sink, S., Scandiani, M. M., A Luque, Colletto, A., Biasoli, M., , Lenzi, L., Salas, G., González, V., Ploper, L. D., Formento, N., Pioli, R. N., Aoki, T., Yang, X. B., and Sarver, B. A. J. 2010. Soybean sudden death syndrome species diversity within North and South America revealed by multilocus genotyping. Phytopathology 100:58-71.

Otani, H., Kohnobe, A., Kodama, N., and Kohmoto, K. 1998. Production of a host-specific toxin by germinating spores of Alternaria brassicicola. Physiol. Mol. Plant. Pathol. 52:285-295.

Palmer, S. C., Saleeba, J. A., and Lyon, B. R. 2005. Phytotoxicity on cotton ex-plants of an $18.5 \mathrm{kDa}$ protein from culture filtrates of Verticillium dahliae. Physiol. Mol. Plant Pathol. 67:308-318.

Pazzagli, L., Cappugi, G., Manao, G., Camici, G., Santini, A., and Scala, A. 1999. Purification, characterization, and amino acid sequence of cerato-platanin, a new phytotoxic protein from Ceratocystis fimbriata $\mathrm{f}$. sp. platani. J. Biol. Chem. 274:24959-24964.

Quayyum, H. A., Gijzen, M., and Traquair, J. A. 2003. Purification of a necrosis-inducing, host-specific protein toxin from spore germination fluid of Alternaria panax. Phytopathology 93:323-328.

Rep, M. 2005. Small proteins of plant-pathogenic fungi secreted during host colonization. FEMS (Fed. Eur. Microbiol. Soc.) Microbiol. Lett. 253:19-27.

Roy, K. W., Lawrence, G. W., Hodges, H. H., Mclean, K. S., and Killebrew, J. F. 1989. Sudden death syndrome of soybean: Fusarium solani as incident and relation of Heterodera glycines to disease severity. Phytopathology 79:191-197.

Roy, K. W., Hershman, D. E., Rupe, J. C., and Abney, T. S. 1997. Sudden death syndrome of soybean. Plant Disease 81:1100-1111.

Rupe, J. C. 1989. Frequency and pathogenicity of Fusarium solani recovered from soybean with sudden death syndrome. Plant Dis. 73:581584.

Salamov, A. A., and Solovyev, V. V. 2000. Ab initio gene finding in Drosophila genomic DNA. Genome Res. 10:516.

Stephens, P. A., Nickell, C. D., and Kolb, F. L. 1993. Genetic analysis of resistance to Fusarium solani in soybean. Crop Sci. 33:929-930.

Tomas, A., Feng, G. H., Reeck, G. R., Bockus, W. W., and Leach, J. E. 1990. Purification of a cultivar-specific toxin from Pyrenophora triticirepentis, causal agent of tan spot of wheat. Mol. Plant-Microbe Interact. 3:221-224.

Tuori, R. P., Wolpert, T. J., and Ciuffetti, L. M. 1995. Purification and immunological characterization of toxic components from cultures of Pyrenophora tritici-repentis. Mol. Plant-Microbe. Interact. 8:41-48.

Walton, J. D. 1996. Host-selective toxins: Agents of compatibility. Plant Cell 8:1723-1733.

Wolpert, T. J., Dunkle, L. D., and Ciuffetti, L. M. 2002. Host-selective toxins and avirulence determinants: What's in a name? Annu. Rev. Phytopathol. 40:251-285

Wrather, J. A., and Koenning, S. R. 2006. Estimates of disease effects on soybean yields in the United States 2003 to 2005. J. Nematol. 38:173-180.

Yokoyama, W. M., Christensen, M., Santos, G. D. and Miller, D. 2006. Production of Monoclonal Antibodies. Curr. Prot. Immunol. 74:2.5.12.5.25. Published online.

Zhang, H.-F., Francl, L. J., Jordahl, J. G., and Meinhardt, S. W. 1997. Structural and physical properties of a necrosis-inducing toxin from Pyrenophora tritici-repentis. Phytopathology 87:154-160.

Ziems, A. D., Giesler, L. J., and Yuen, G. Y. 2006. First report of sudden death syndrome of soybean caused by Fusarium solani f.sp. glycines in Nebraska. Plant Dis. Note 19:106-107.

\section{AUTHOR-RECOMMENDED INTERNET RESOURCES}

Center for Biological Sequence Analysis servers: www.cbs.dtu.dk Expasy Findmod tool: ca.expasy.org/tools/findmod 